\title{
Evolution of iron crust and clayey Ferralsol in deeply weathered sandstones of Marília Formation (Western Minas Gerais State, Brazil)
}

\author{
Vania Rosolen ${ }^{\text {a, }}{ }^{*}$, Guilherme Taitson Bueno ${ }^{\text {b }}$, Adolpho José Melfi c, d, \\ Célia Regina Montes ${ }^{\mathrm{d}}$, Carla Vanessa de Sousa Coelho ${ }^{\mathrm{a}}$, Débora Ayumi Ishida ${ }^{\mathrm{c}, \mathrm{d}}$, \\ José Silvio Govone ${ }^{\mathrm{e}}$ \\ ${ }^{a}$ Universidade do Estado de São Paulo (UNESP), Departamento de Petrologia e Metalogenia (DPM), Av. 24A, 1515, Bela Vista, Rio Claro, SP CEP: 13506-900, \\ CP: 178 , Brazil \\ b Universidade Federal de Goiás (UFG), Instituto de Estudos Sócio-Ambiental (IESA), CEP: 74001-970 Goiânia, GO, Brazil \\ ${ }^{\mathrm{c}}$ University of São Paulo (USP), Núcleo de Pesquisa em Geoquímica e Geofisica da Litosfera e Instituto de Energia \& Ambiente (NUPEGEL/IEA), CEP: \\ 13418900 Piracicaba, SP, Brazil \\ d Universidade de São Paulo (USP), Centro de Energia Nuclear na Agricultura e Núcleo de Pesquisa em Geoquímica e Geofísica da Litosfera (CENA/NUPEGEL), \\ CEP: 13418900 Piracicaba, SP, Brazil \\ e Universidade do Estado de São Paulo (UNESP), Centro de Estudos Ambientais (CEA), CEP: 13506-900 Rio Claro, SP, Brazil
}

\section{A R T I C L E I N F O}

\section{Article history:}

Received 13 April 2017

Received in revised form

24 July 2017

Accepted 6 September 2017

Available online 7 September 2017

\section{Keywords:}

Marília formation

Sandstone

South American surface

Ferricrete

Pisolites

Clayey Ferralsol

\begin{abstract}
A B S T R A C T
Extensive flat plateaus are typical landforms in the cratonic compartment of tropical regions. Paleoclimate, pediplanation, laterization, and dissection have created complex and distinct geological, geomorphological, and pedological features in these landscapes. In the Brazilian territory, the flat plateau sculpted in sandstone of Marília Formation (Neocretaceous) belonging to the Sul-Americana surface presents a very clayey and pisolitic Ferralsol (Red and Yellow Latossolo in the Brazilian soil classification). The clayey texture of soil and the pisolites have been considered as weathering products of a Cenozoic detritical formation which is believed to overlay the Marilia Formation sandstones. Using data of petrography (optical microscopy and SEM), mineralogy (RXD), and macroscopic structures (description in the field of the arrangement of horizons and layers), a complete profile of Ferralsol with ferricrete and pisolites was studied. The complex succession of facies is in conformity with a sedimentary structure of Serra da Galga member (uppermost member of Marília Formation). The hardening hematite concentration appears as layered accretions in the subparallel clayey lenses of sandstone saprolite, preserving its structure. Iron contents varied according to different soil fabrics. Higher concentrations of iron are found in the massive ferricrete or in pisolites in the mottled horizon. Kaolinite is a dominant clay mineral and shows two micro-organizations: (1) massive fabric intrinsic to the sedimentary rock, and (2) reworked in pisolites and illuviated features. The pisolites are relicts of ferricrete in the soft bioturbated topsoil. The continuous sequence of ferricrete from saprolite to the Ferralsol indicates that the regolith is autochthonous, developed directly from sandstones of Marília Formation, through a long and intense process of laterization.
\end{abstract}

(c) 2017 Elsevier Ltd. All rights reserved.

\section{Introduction}

Extensive flat plateaus are typical landforms in the stable platforms of tropical regions. In Brazil, these surfaces were sculpted

\footnotetext{
* Corresponding author.

E-mail addresses: vrosolen@rc.unesp.br (V. Rosolen), gtaitson@ig.com.br (G.T. Bueno), ajmelfi@usp.br (A.J. Melfi), crmlauar@usp.br (C.R. Montes), deboraishida@yahoo.com.br (D.A. Ishida), jsgovone@rc.unesp.br (J.S. Govone).
}

during and after the upper Cretaceous, and have been inserted in the Sul-Americana surface proposed by King (1956). The old plateaus in the tropical regions exhibits a complex geological, geomorphological, and pedological features inherited from cyclic paleoclimatic events which resulted in pediplanation, laterization, and dissection by incising river channels (Butt et al., 2000). The result is a thick, commonly lateritic regolith, protected by surface hardening ferruginous (duricrust or ferricrete) or by soft ferruginous and aluminous pisolitic horizon (Nahon, 1991). 
Uncertainties or lack of information on weathering and soil formation in old landscape of tropics exist until now, and the more precise characterization of the distinct regoliths constitutes in problems and opportunities, relating to geological, geophysical and geochemical mapping, and exploration techniques (Twidale and Bourne, 1998; Butt et al., 2000; Beauvais et al., 2004; Chardon et al., 2006).

In the Brazilian territory, in the northern border of the sedimentary Paraná Basin (region of Triângulo Mineiro in Minas Gerais State), the Sul-Americana surface comprise flat plateaus from 950 to $1050 \mathrm{~m}$ of altitude (Baccaro, 1991). The extensive plateaus (tablelands $=$ chapadas) covered by cerrado vegetation were built on sedimentary rock of Marília Formation (Neocretaceous). After upward movements, weathering and water erosion, their border was sculpted exposing the horizontal layers of the sandstone and the soil profile. The soil is very clay Ferralsol with ferruginous nodules and pisolites. The clayey texture and the pisolites are two characteristics that have been posing doubts about the origin and affiliation with the underlying sedimentary rock. For example, the natural resources survey published by the RadamBrasil (Mamede et al., 1983) based on edaphostratigraphy, considered that the profiles of Ferralsol were developed from allochthonous detrital material of Cenozoic. This supposed Cenozoic material would correspond to an extensive sedimentary post-Marília event, which covered the most part of the Brazilian Central Plateau, including the plateau of Triângulo Mineiro. After its deposition, the more humid climate favored the pedogenesis, forming Ferralsol and ferruginous nodules. Similar assumption was presented in the geological mapping of the Minas Gerais state (CPRM, 2003). In both publications, the regolith with ferruginous materials was characterized as a Cenozoic detritus-cover having uncertain genesis and unknown origin. The texture of soil is the more important characteristic in which some authors have suggested the independence between bedrock (sandstone) and soil (Ferralsol). Following this conception, the clayey sediments and the ferruginous detritus were characterized as a product of colluvio-elluvial Quaternary sedimentation (Fernandes, 1998; Motta et al., 2002; Marques et al., 2004).

The interpretation reflects the complexity to determine the role of pedogenesis in the development of deep regolith in the old and tectonically stable compartment of tropics, although it is frequent in this landscape the clayey soil cover with continuous ferricrete or discontinuous gravel-size ironstones as a product of the intensive action of water and elevated temperature in a long period of time (Chardon et al., 2006). The difficulty to understand the relationships between rock and soil is mainly due to the great thickness of tropical regoliths, and the complex evolution of the landscapes in which they occur, implicating the geochemical changes linked to paleoclimatic conditions, regional uplift and the erosive/depositional processes that control the preservation and occurrence of specific regolith units (Butt et al., 2000).

Theories on the genesis of ferruginous concretions in soils and weathering profiles indicating current and past tropical weathering and pedogenesis continue to be debated (Löhr et al., 2010; Eze et al., 2014).

In the study, the soil landscape exhibits a ferricrete (hardened iron crust) overlaid by a superficial horizon of Ferralsol (with pisolites) over the argillaceous sandstones of Serra da Galga Member, which represents the top of the sedimentary sequence of Marilia Formation, deposited in semi-arid to arid hot climate (Ribeiro, 2001).

The objective of this paper is to present data of one typical plateau profile which indicate that the ferricrete and pisolites cover is formed directly from the argillaceous sandstone of Marília Formation. Classical methods as microscopy and chemical and mineralogical analysis were employed. The results contribute to improve the knowledge on the role of pedogenesis for the history of the old tropical landscapes.

\section{Material e methods}

\subsection{Description of field site and investigative methods}

A complete profile is exposed in an outcropping on the steep edge of the plateau situated in the Federal Road BR-050, km 127, at $50 \mathrm{~km} \mathrm{~N}$ from the city of Uberaba (Minas Gerais State) $\left(19^{\circ} 20^{\prime} 20^{\prime \prime} \mathrm{S}\right.$ $-53^{\circ} 56^{\prime} 14^{\prime \prime} \mathrm{W}$ ) (Fig. 1).

The outcropping is at $943 \mathrm{~m}$ of altitude. The landscape consists of a flat plateau dissected on its edges presenting closed and waterlogged topographic depressions on its tops. The open savannah (Cerrado s.s.) covers the flat surface of the plateau, and is locally interrupted by the appearing of hydromorphic fields developed in the topographic depressions covered by dense herbaceous stratum.

The profile is $6 \mathrm{~m}$ thick, and exhibits three main horizons. They are from the top to the bottom: (I) Ferralsol with pisolites; (II) indurated iron crust horizon (ferricrete); and (III) clayey mottled horizon (Fig. 2).

(I) 0-230 cm depth: a nodular surface horizon, friable, clayey sand, pale red with subspherical $(<1 \mathrm{~cm})$ purple-red and red pisolites. Quartz composes the sand fraction. The boundary to underlying horizon is progressive and undulating, with increasing of dark-red and red hard-iron facies. The light red and yellow facies correspond to $40 \%$ of the soil.

(II) $230-340 \mathrm{~cm}$ depth: the ferricrete is characterized by the juxtaposition of round and indurate nodules (80\% of the matrix). The purple red nucleus is extremely hard, and their periphery is red with yellow cortex. Grains of quartz $(<0.5 \mathrm{~mm})$ are cemented in their nucleus. Nodular structure occurs in parallel layers according sedimentary structure.The transition horizon between the ferricrete and the mottled clay is at $340-400 \mathrm{~cm}$ depth. The boundary is smooth. The preserved nucleus of the ferricrete is purple, extremely hard, and it is encompassed in a friable red, yellow and gray clayey spot.

(III) 400-600 cm depth: the mottled clayey layer. The bedrock is deeply weathered but the sedimentary structure is recognized. The clayey matrix is laminated alternating red and yellow lenses and/or light gray or white spots. The light gray and white spots are compact, constituted by very fine clay. The thickness of the layers varies from 0.2 to $3 \mathrm{~cm}$. The color transition is clear and abrupt.

The plateau is developed on sedimentary rock of Marilia Formation (Neocretaceous), constituted by the members Ponte Alta and Serra da Galga (inferior and superior in the stratigraphic column). The lithology corresponds from fine to very coarse massive sandstones, cross-stratified or ripple cross-laminated with rare mudstones (Menegazzo et al., 2006). The fundamental difference between Ponte Alta and Serra da Galga members is the chemical composition of the matrix. Whereas the immature sandstones of Ponte Alta are cemented by calcium carbonate, the matrix of Serra da Galga is clayey and silicified, displaying in parallel horizontal structure (Suguio, 1973). The regional climate is tropical, having a warm and humid season from September to March, and a dry season from April to August. The average annual rainfall is $1500 \mathrm{~mm}$, and the average annual temperature is $24^{\circ} \mathrm{C}$ (Silva et al., 2008).

The field description of soil, ferricrete and saprolite was carried out using the guide for soil description according to the FAO system 


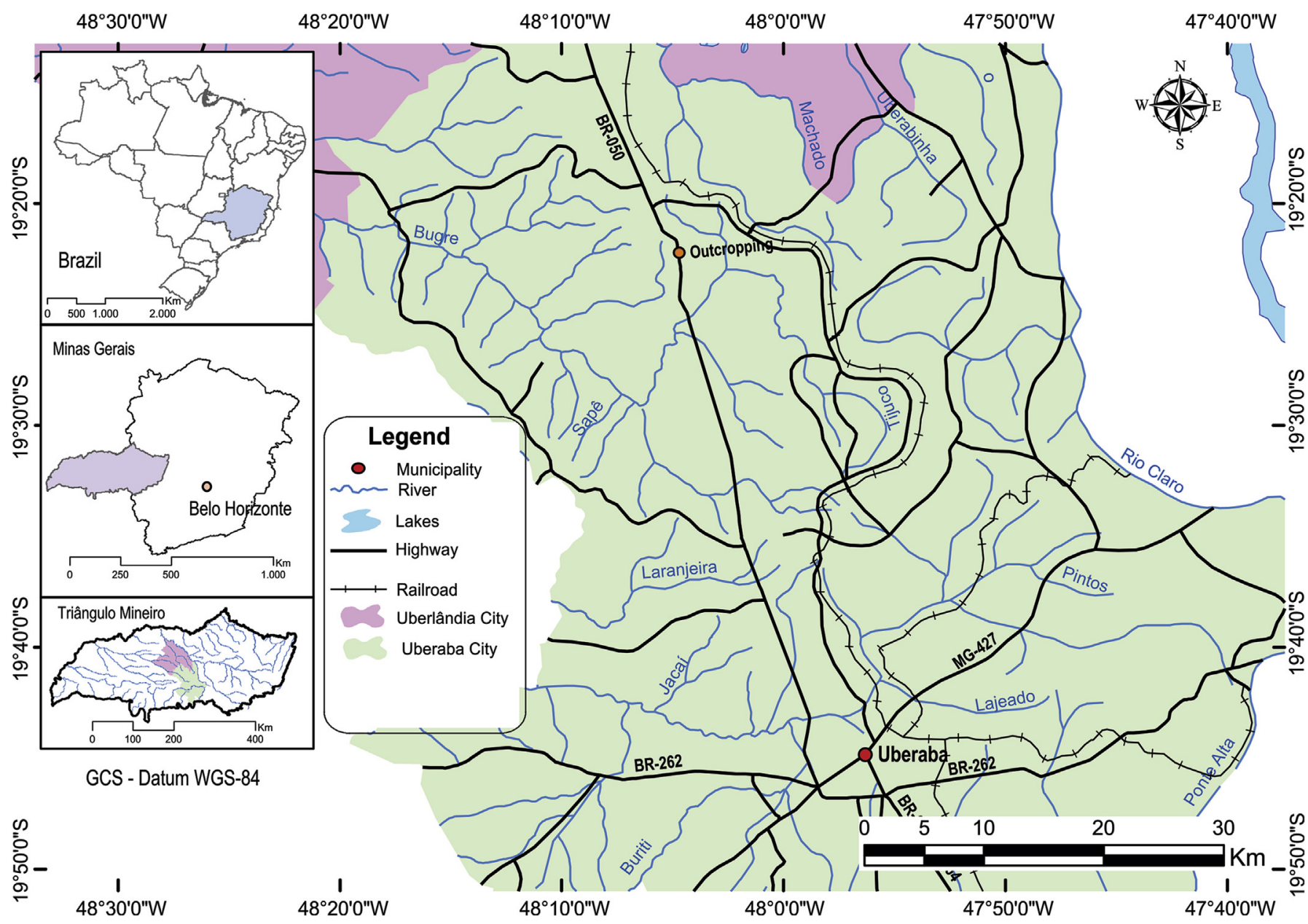

Fig. 1. Localization of the study of area in the plateau of Uberaba (Minas Gerais State, Brazil).

(IUSS WRB, 2006), and the methods to describe sedimentary rock according to Tucker (2014). The described morphological characteristics were thickness of soil and saprolite horizons, texture, color, sedimentary texture and structure, oxido-reduction and pedological features.

Undisturbed samples were collected in all soil and saprolite horizons, including different facies within each. The term "facies" is used here as was proposed by Nahon et al. (1977), representing the whole of the petrographic and textural characteristics of a rock or soil. The undisturbed samples were impregnated with a polyester resin, cut in thin sections and polished sections of $3 \times 4.5 \mathrm{~cm}$. Micromorphological analyses were performed using an optical microscope Zeiss Axioskop 40 integrated with a 5.0 megapixels Canon digital camera, and with the software EOS 5D Mark II. Weatherable minerals of rock was analyzed using a scanning electron microscopic (SEM) JEOL, JSN 5600 LV. The terminology used to describe the micromorphological features in thin sections was made according Stoops et al. (2010).

The particle size was determined using methods from EMBRAPA (1997). After vertical shaking for $16 \mathrm{~h}$, the silt and clay contents were determined by the pipette method, using sodium hexametaphosphate solution as dispersant and the sand by sieving.

For the analysis of major chemical elements of soils by X-ray fluorescence (FRX), samples were air-dried, ground with a mortar and pistle of agata, and sieved at $<0.05 \mathrm{~mm}$. The samples were fused with lithium tetraborate 1:9. The detection limits were of the order of $0.1 \mathrm{~g} \mathrm{~kg}^{-1}$ for $\mathrm{SiO}_{2}, \mathrm{Al}_{2} \mathrm{O}_{3}$, and $\mathrm{Fe}_{2} \mathrm{O}_{3}$, and of the order of
$0.01 \mathrm{~g} \mathrm{~kg}^{-1}$ for $\mathrm{MgO}, \mathrm{CaO}, \mathrm{P}_{2} \mathrm{O}_{5}, \mathrm{Na}_{2} \mathrm{O}, \mathrm{K}_{2} \mathrm{O}$, and TiO. The index of weathering was made using the criteria CIW $\left(\mathrm{CIW}=\mathrm{Al}_{2} \mathrm{O}_{3}\right.$ / $\left.\left(\mathrm{Al}_{2} \mathrm{O}_{3}+\mathrm{CaO}+\mathrm{Na}_{2} \mathrm{O}\right) \times 100 \%\right)$ proposed by Harnois (1988) considering the $\mathrm{A}_{2} \mathrm{O}_{3}$ as the immobile component.

The mineral composition was obtained by X-ray diffraction (XRD) Phillips Expert PW 3710, potential of $40 \mathrm{kV}$, using monochromator for elimination of $\mathrm{K} \beta$ radiation, and source of $\mathrm{Cu}(\mathrm{Ka}$ radiation, $\lambda=1.54186 \AA$ ). Scanning was performed with step $0.02^{\circ}$ $(2 \theta)$ and time of $10 \mathrm{~s}$ per step accumulation.

\section{Results and discussion}

\subsection{Structural characteristics and petrography on the evolution of the ferruginous profile}

In the macroscopic observations (Fig. 2), the mottled layer (III) is clayey (59\% of clay, and $31 \%$ of sand) and consists of a network of spots ( $3-5 \mathrm{~cm}$ diameter) light gray, dark red and yellow. Yellow spots gradually develop at the expense of the dark red, while a small $(<0.5 \mathrm{~mm})$ yellow and red spots appear inside the light gray. The border between white and red spots is sharp. In the upper part of this layer, the dark red spots became increasingly indurate forming ferruginous nodules encompassed by soft and clayey pale red matrix. The network of light gray spots is interrupted in the transition with the ferricrete. The transition between the mottled layer and the ferricrete is progressive and irregular, consisting essentially of three domains: indurated nodules (dark red), soft 


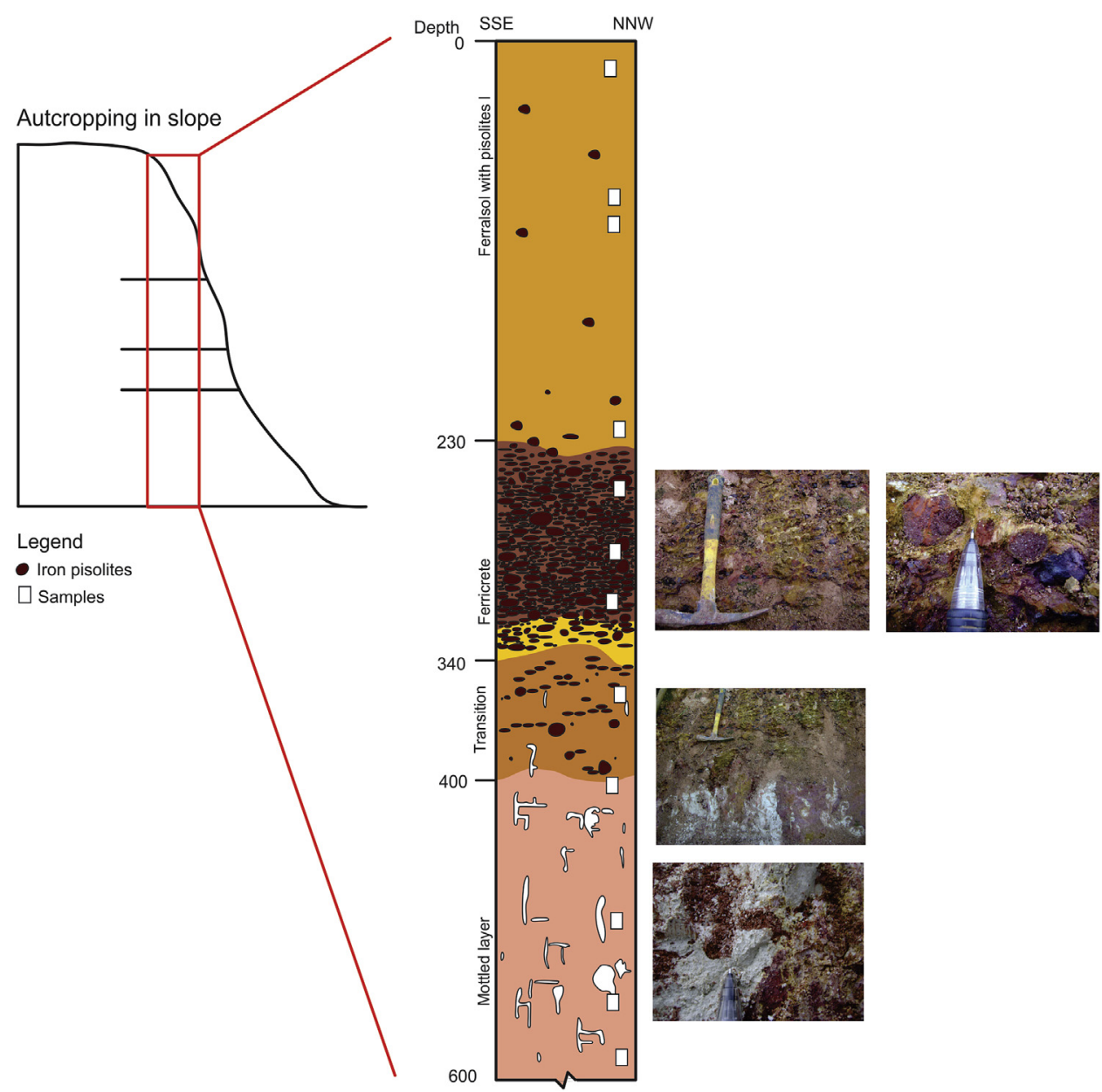

Fig. 2. Sketch of a typical undisturbed profile showing the (III) mottled layer; (II) ferricrete; (I) Ferralsol with pisolites.

yellow and red clayey matrix. Locally, the gray arrays are present as a thin layer $(<1 \mathrm{~cm})$ according to the horizontal pre-existing structure of the sandstone. The progressive increase of size and hardening of nodules indicates oxidative conditions (McKay et al., 2005).

The ferricrete (II) is composed by coalescent centimeter-sized nodules which have in their cores the cemented grains of quartz. The hard and purple-red hematitic nodules are separated from each other by yellow and red soft material. Some nodules show irregular external limit, penetrated by yellow-red to red digitations. Yellow clay and cortex in the periphery of the nodules increase toward the top and the bottom of the ferricrete. Clearly the nodules develop according to the pre-existing structure of the sandstone, while the pale red and yellow material are developed at the expense of the nodules. The content of clay is of $67 \%$ and the sand is $25 \%$.

The Ferralsol with pisolites layer (I) overlays the ferricrete, and consists of a soft, clayey and pale red matrix with ferruginous nodules. The soil is friable having an expressive network of biological and structural pores. The boundary between the ferricrete and the pisolitic horizons is progressive, with a reduction of the size and occurrence of nodules, and shows an increase of quartz grains.

In the field, the pre-existing planar and parallel stratification of sedimentary bedrock is recognized in the mottled horizon and in the ferricrete layer indicating that the iron crust was formed in the saprolite sandstone. The advance of the front of ferrugination with hematite into the saprolitic level is possible since the climatic conditions are suitable and persistent (Beauvais, 1999).

The occurrence of the millimetric to centimetric gray layers within the ferricrete is an indicative of a preferential circulation of water which follows the sub-horizontal structure. These modern features results from iron loss from the pre-existing ferricrete. Similarly, in the mottled layer, the light gray spots are made by iron depletion, and the features indicate reducing conditions by periodically soil-water saturation (Hong et al., 2010).

Upward, the transition from ferricrete to Ferralsol is progressive, transforming the crust in a gravel horizon. Small nodules (pisolites) are dispersed in a pale red and weakly structured matrix characteristic of the Ferralsol. Nodules and ferricrete debris have similar petrographic facies.

Under optical microscopy, the original lithic fabric (planar and parallel stratification of the sandstone) is also clearly identified in the ferricrete and in the mottled layer. In the topsoil, only small fragments of the sandstone could be found within the soft matrix. The increase of pedoturbation in the soft nodular uppermost horizon over ferricrete associated with the intensive weathering and laterization are responsible for the gradual reduction of the saprolitic facies since the pedogenetic process deeply modify the lithic structure and texture (Nahon, 1991).

In the groundmass, relicts of the saprolite show internal fabrics modified by pedoplasmation and iron concentration (Fig. $3 \mathrm{~A}$ and $\mathrm{B}$ ). Hematite is concentrated in massive and continuous zones or in pisolites (Fig. 3A, B, 3C and 3D). Both massive and nodular ferricrete are formed by absolute Fe accumulation driven by oxidative process (Beauvais, 1999; McKay et al., 2005). The hematite has a mineralogical affinity with kaolinite, precipitating when the porosity of the clay matrix is low (Didier et al., 1983). 

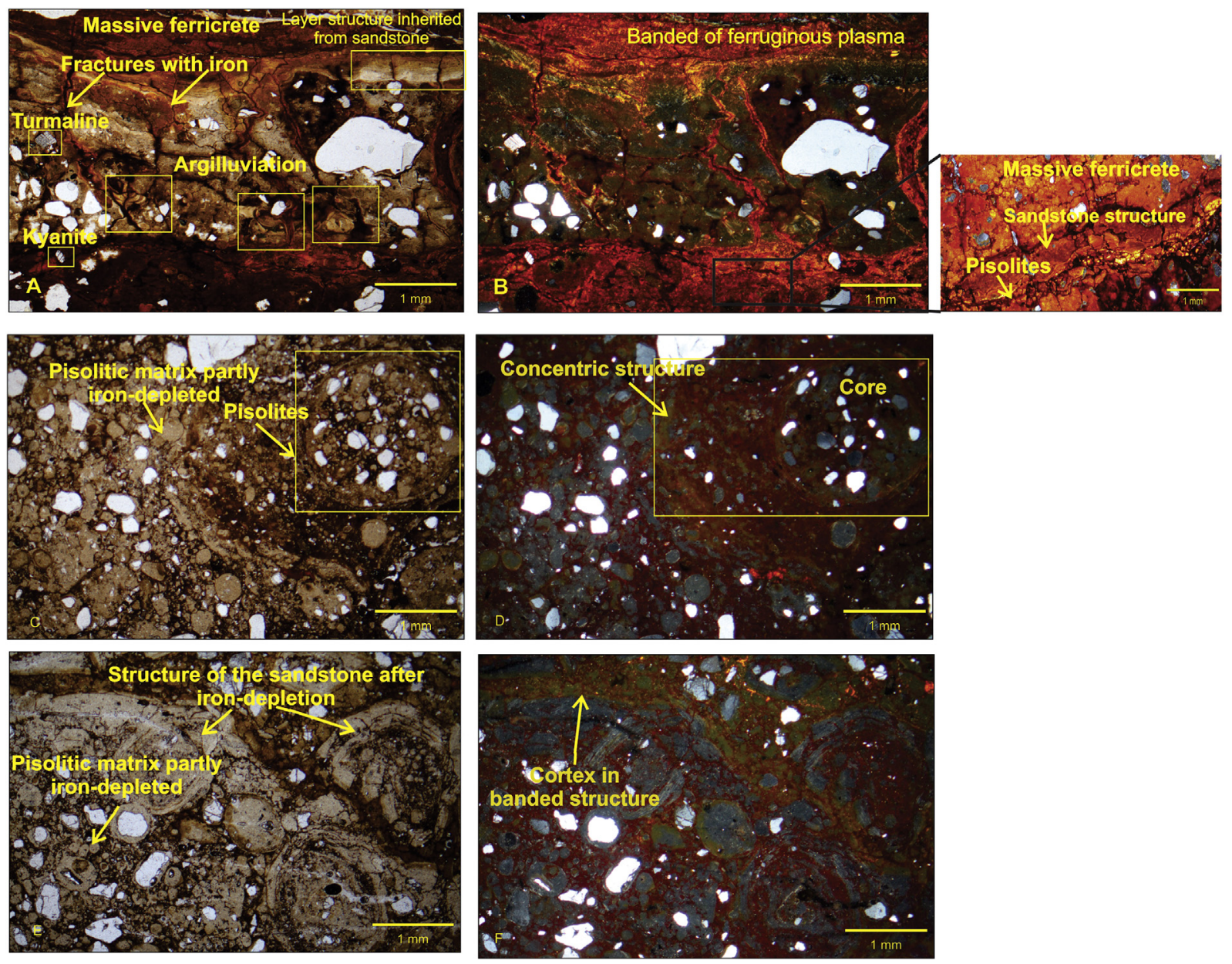

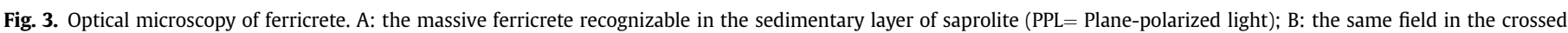

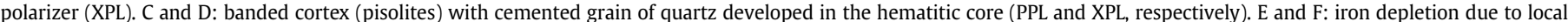
reduction (PPL and XPL, respectively).

The dominant massive microstructure typical of the ferricrete embeds the platy microstructure forming a banded arrangement of ferruginous dark red, red and yellow fine materials, interspersed with gray sheets formed by iron depletion (Fig. 3A and B). Numerous fractures (planar voids) parallel and perpendicular to the layers are infilled with ferruginous dark red material, in continuity with massive ferricrete. The microstratification varies in color and composition. The grey layers are constituted by kaolinite, and the red and yellow layers by accumulations of Fe oxides. According to Nahon (1991), the lighter red and yellow bands in cortex consist of aluminous goethite $(16-22 \mathrm{~mol} \%$ of $\mathrm{AlOOH})$ resulting from the destruction of the kaolinite-hematite matrix.

Ferruginous nodules (dark red) with complex coatings (banded cortex according Nahon, 1991) cementing grains of quartz in the hematitic core are associated with massive iron accumulation (Fig. 3C, D, 3E and 3F). Its fabric indicates that the concentric red and yellow coating develops at the expense of the dark red nucleus. During the process, it is normal to have a progressive enrichment of aluminum associated with the development of yellow domains, which is even more marked when the ferruginous crust is dismantled (Muller and Bocquier, 1986). The pisolites fabric remained after deferrugination.

Kaolinitic micromass dominates all over the profile, and it is organized in two differentiated fabrics. The first one is non- oriented and massive, intrinsic to the sedimentary rock (Fig. 3A and B). Previous studies have characterized clayey layers in the sandstone of Marília Formation. Suguio (1973) described argillaceous sandstone and red claystone belonging to the outcropping of Serra da Galga Member. Ribeiro (2001) characterizes this member from feldspar sandstone to subarcosean consisting of sandstone, claystone, and siltstone layers. The low mechanical compaction of sediments during the diagenesis allowed that structural pores were infilled by diagenetic clay composed by kaolinite (Ribeiro, 2001). Kaolinite can be hosted in sediments under near-ambient conditions or down in the physical-chemical stages of diagenesis in sandstones (Lanson et al., 2002).

The second fabric refers to the reworking of clay minerals to form pisolites (Fig. 3C, D, 3E, 3F and Fig. 4A, B), and modern features of clay illuviation recognizable in continuous and orientated clay particles (Fig. 4C, D, 4E and 4F). Nodules are a three-dimensional structure made by centripetal fine material accumulations while the segregation of clay is a result of mechanical internal stress by the alternation of wetting and drying cycles (Ambrosi and Nahon, 1986; Nahon, 1991).

In the mottled layer, the saprolite fabric is still recognizable (Fig. 4A and B), and the grey pisolites indicate iron depletion (Fig. 4A and B).

Hypocoating (yellow color) is found in the wall of pores (Fig. 4C 

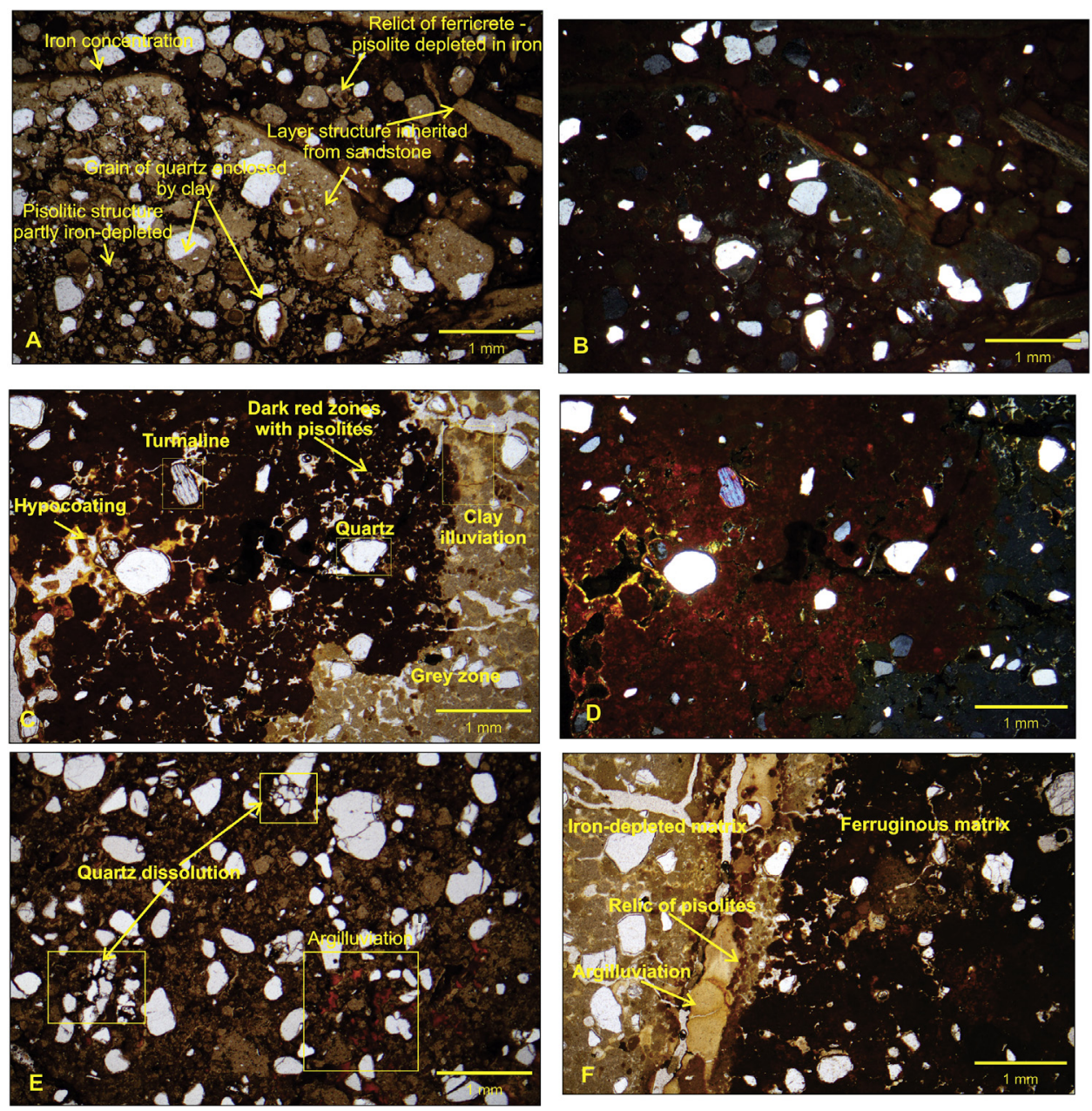

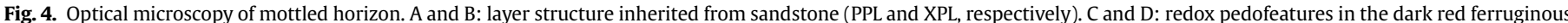

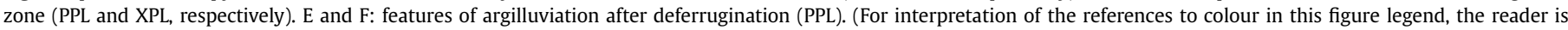
referred to the web version of this article.)

and D), and limpid fine clay occurs as coatings or infilling the voids. The degradation of ferruginous groundmass favors the kaolinite clay dispersion (Fig. 4C, D, E, and F). Kaolinite coating is more intense in the zones where the iron has been lost (Fig. 4F).

Rare relics of saprolite are found in the soft nodular horizon (Fig. 5A and B). The pedo-bioturbation is dominant in this horizon, and the resulted network of pores enhances the illuviation of kaolinite particles (Fig. 5C and D). Bioturbation is the main process contributing to the destruction of the saprolite fabric (Stoops et al., 2010).

In zones where the fine materials are leached, the coarse materials (pisolites) are organized in packing pores (Fig. $5 \mathrm{E}$ and F).

In the whole profile, the coarse materials are similar, consisting of resistant minerals as quartz, and rare zircon, tourmaline, kyanite, and rutile. Quartz grains are partially corroded, showing fissured infilled by illuvial ferruginous clay and they can be fractured in small grains increase silt fraction (Fig. 6 A). Also, weathered mineral grains show different patterns of weathering and development of secondary phase (alteromorph according to Delvigne, 1998), e.g., crystal of biotite is ferruginized, and the more resistant minerals are partially dissolved and infilled with iron and clay materials (Fig. 6 B, C, and D).

The constitution of primary minerals (coarse materials) in the studied profile is uniform, in accordance with that described as the source of Marília Formation sediments in the Triângulo Mineiro.
Dias-Brito et al. (2001) attribute to the metasedimentary rocks of the Araxá Group, located at N and NE around the basin, the mainly source of sediments to form the Marília sandstone. The mineral composition of soil is coherent with that proposed for the rocks of Araxá Group presented by Zanardo et al. (1996).

\subsection{Chemical properties and mineralogical characteristics}

The main chemical properties obtained in the layers of the outcropping are summarized in Table 1 . The $\mathrm{pH}$ is acidic ( 4.6) and does not vary in the profile. The entire profile presents a low BS reflecting the intense leaching of its basic cations. The exchangeable cations $\mathrm{Ca}, \mathrm{Mg}$ and $\mathrm{K}$ are in very low concentration, reflecting the clay mineralogy and intensive leaching. Applying the CIW index (Harnois, 1988), the horizons of the profile have similar trend showing values $>99 \%$, indicating the deep chemical weathering. The sum of oxides of $\mathrm{Mg}, \mathrm{Ca}, \mathrm{Na}$ and $\mathrm{K}$ is low ( $<0.3 \%)$, reflecting depletion of mobile elements typical of laterite. The contents of $\mathrm{Fe}_{2} \mathrm{O}_{3}$ vary according to the facies. In the mottled layer, where the red spots predominate, the content of $\mathrm{Fe}_{2} \mathrm{O}_{3}$ is of $38 \%$. The contents of $11 \%$ were determined in the grey and yellow spots. In the Ferralsol layer, the range in the contents of the oxides is lower than the mottled and ferricrete layers which is attributed by the degradation of ferricrete and by pedo-bioturbation, both contributing to homogenize the soil matrix (Tardy, 1993). According to this author, the 

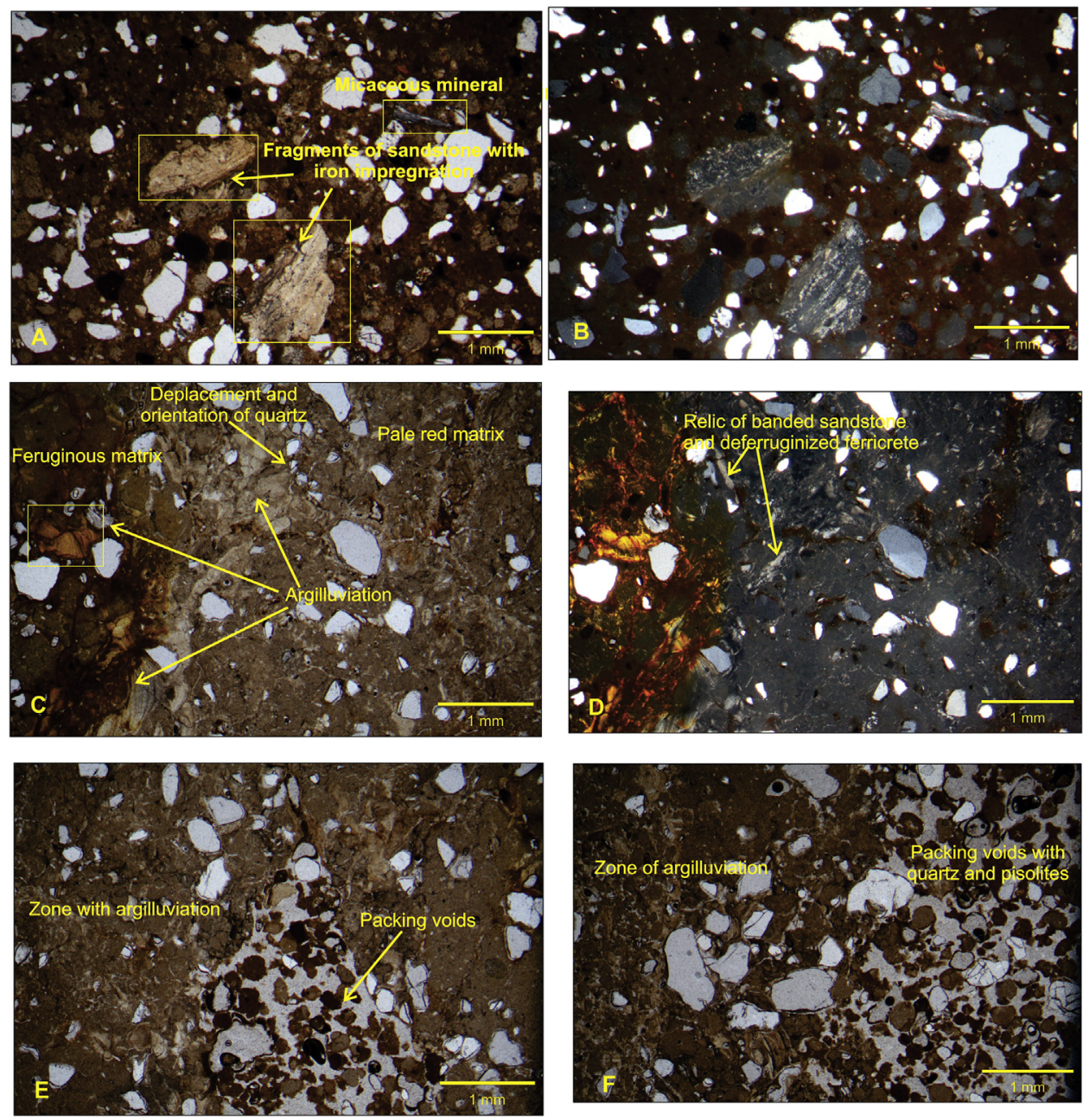

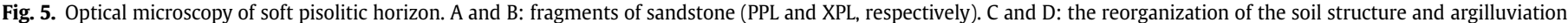
(PPL and XPL, respectively). E and F: zones where plasma is leached forming packing voids (PPL).

gain and loss of chemical elements in a lateritic profile is a matter of the scale in which absolute and relative enrichments are closely related to the petrological facies constitutive of the lateritic profile. The higher content of $\mathrm{SiO}_{2}$ (70\%) in the pisolitic horizon is related to the relative increase of quartz content, which is expected when ferricrete is degraded (Beauvais, 2009).

The mineralogical results obtained for the sandstone, the mottled layer, the ferricrete, and the pisolitic topsoil show a similar constitution. In the sandstone predominates quartz, kaolinite, goethite, hematite, and gibbsite.

\subsection{SEM observations}

Relics of sandstone saprolite were found in all horizons, diminishing in the top. The preservation of pre-existing structure is favored in ferricrete because iron cementation protects the structure of sandstone. SEM observation on a ferricrete horizon shows a massive microstructure of iron-rich crust which is destructed by the opening of pores. Surrounding them, greyish spots are created after the loss of iron (Fig. 7A). After deferrugination, relics of nodules (pedorelics, sensu Nahon, 1991) are preserved (Fig. 7A) and zones with illuviated and orientated kaolinitic clay appear indicating the movement of fine material (Fig. 7B). The weakly differentiated accumulation indicates initial concentration, showing structural, geochemical, and mineralogical relationships with the surrounding matrix (Nahon, 1991). Pedorelics of pisolites inside the grayish spots are also found in the mottled layer (Fig. 7C) indicating affiliation between them and the ferricrete. Orientated grains of quartz are found in the border of pisolites indicating the displacement of the coarse fraction by the reorganization of fine materials. Finally, the presence of the primary weathered mineral (e.g., rutile) in the soft pisolitic horizon indicates the vertical similarity, from the bottom to the top of the profile.

\subsection{Hypothesis on autochthonous evolution between clayey Ferralsol and the sandstone of Marília Formation}

Macro-micromorphological observations and laboratory analysis carried out on the typical profile clearly suggest affiliation between the ferricrete and the sandstone of Marília Formation (Serra da Galga Member), and the clayey Ferralsol with pisolites was formed by the dissolution of the ferricrete. The ferricrete was formed directly from the saprolitic layer of the argillaceous sandstone, preserving the pre-existing structure. The processes of deep weathering, the original enrichment in kaolinite of the sandstone, the age of the plateau, and the paleoclimatic changes have been favorable to the formation of clayey Ferralsol.

According to Tardy et al. (1991), during the Eocene (50 My B.P.) an extensive phase of more humid climatic conditions with distinct seasonality dominate in the South America, and it was responsible 



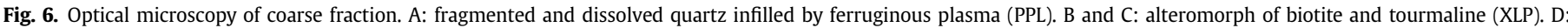
dissolution of kyanite (PPL).

for the formation of ferruginous crust. The chronology of the lateritic crust carried out in Brazilian Amazon and in the Quadrilátero Ferrífero (Minas Gerais State) confirmed the age of 72 and 55 My B.P., respectively (Vasconcelos et al., 1994; Monteiro et al., 2014). In recent time, the more humid climate propitiates the incision of rivers, fragmenting plateau, and the chemical and physical dismantling of the ferruginous crust forming profiles composed by mottled and pisolitic horizons (Tardy, 1993; Beauvais, 2009). In the studied profile, the spots are a result of frequent rise and fall of groundwater under seasonally warm and humid climatic conditions. This condition provides the opening of cracks and fissures that favor water movement in soils, generating gray spot in red matrix (Hong et al., 2010). Hipocoatings and quasicoatings (Lindbo et al., 2010) are found bordering iron-depleted grey zones.

The increase of redox pedofeatures results in the relative reduction of the dark red ferruginous zone, which decreases and becomes discontinuous. After iron loss, clay particles become unstable (Nahon, 2003) allowing its dispersion and sedimentation in the small soil pore (features of argilluviation).
The formation of pisolites has been also associated with the degradation of laterites, and in general, these features are the results of the destruction of the preexisting ones, developed in situ by progressive leaching process (Boulangé, 1984; Nahon, 1991). Following geochemical processes, the physical degradation of ferricrete results in deplacement of pisolites and quartz, mechanically transferred from other parts of the profile. As observed in the mottled horizon, clay illuviation associated with internal water flux is remarkable. Mottled features are an indicator of contemporary pedogenic processes (Singh and Gilkes, 1996). Its genesis is closely related to the increase of the hydromorphic conditions caused by climatic changes and/or by pedobioclimatic unbalance (Nahon et al., 1989; Beauvais, 2009) in which red soils with white veins develops at the transition from the weathered bedrock up to the lateritic duricrust (Tardy and Roquin, 1992; Hong et al., 2010). So, the grey spots are a modern feature driven by warmer and more humid climatic conditions than those necessary for the formation of ferricrete.

The sequence of the sedimentation, paleoclimatic and

Table 1

The main chemical features of mottled, ferricrete and Ferralsol with pisolites layers.

\begin{tabular}{|c|c|c|c|c|c|c|c|c|c|c|c|c|c|c|}
\hline \multirow[t]{2}{*}{ Profile } & \multirow[t]{2}{*}{ Depth } & \multirow[t]{2}{*}{$\mathrm{pH}$} & \multirow[t]{2}{*}{ BS } & \multicolumn{3}{|c|}{ Exchangeable bases } & \multirow[t]{3}{*}{$\mathrm{SiO}_{2}$} & \multirow[t]{3}{*}{$\mathrm{Al}_{2} \mathrm{O}_{3}$} & \multirow[t]{3}{*}{$\mathrm{Fe}_{2} \mathrm{O}_{3}$} & \multirow{3}{*}{$\begin{array}{l}\mathrm{TiO}_{2} \\
\overline{\mathrm{Wt}(\%)}\end{array}$} & \multirow[t]{3}{*}{$\mathrm{P}_{2} \mathrm{O}_{5}$} & \multirow[t]{3}{*}{$\mathrm{MgO}+\mathrm{CaO}+\mathrm{Na}_{2} \mathrm{O}+\mathrm{K}_{2} \mathrm{O}$} & \multirow[t]{3}{*}{ LOI } & \multirow[t]{3}{*}{ CIW } \\
\hline & & & & $\mathrm{Ca}$ & $\mathrm{Mg}$ & K & & & & & & & & \\
\hline Horizon & $\mathrm{cm}$ & $\overline{\mathrm{CaCl}_{2}}$ & \multicolumn{4}{|c|}{ mmolc.dm ${ }^{-3}$} & & & & & & & & \\
\hline Pisolitic & 10 & 4.5 & 0.3 & $<1$ & $<1$ & $<0.2$ & 51,8 & 24,8 & 11,7 & 1,3 & 0,12 & 0,2 & 10,0 & 99,7 \\
\hline Pisolitic & 50 & 4.5 & 0.2 & $<1$ & $<1$ & $<0.2$ & 70,4 & 17,6 & 4,3 & 0,8 & 0,05 & 0,3 & 6,5 & 99,4 \\
\hline Ferricrete & 200 & 4.6 & 0.2 & $<1$ & $<1$ & $<0.2$ & 32,8 & 22,3 & 32,6 & 1,2 & 0,11 & 0,3 & 10,7 & 99,8 \\
\hline Ferricrete & 350 & 4.5 & 0.2 & $<1$ & $<1$ & $<0.2$ & 41,5 & 23,6 & 22,4 & 1,3 & 0,07 & 0,1 & 10,9 & 99,7 \\
\hline Mottled & 500 & 4.5 & 0.2 & $<1$ & $<1$ & $<0.2$ & 55,7 & 22,4 & 11,0 & 1,4 & 0,05 & 0,1 & 9,3 & 99,7 \\
\hline Mottled & 600 & 4.6 & 0.2 & $<1$ & $<1$ & $<0.2$ & 31,2 & 18,3 & 38,5 & 0,9 & 0,12 & 0,1 & 10,8 & 99,7 \\
\hline
\end{tabular}

$\mathrm{BS}=$ Base Saturation; $\mathrm{LOI}=$ Los on ignition; $\mathrm{CIW}=$ chemical index of weathering. 



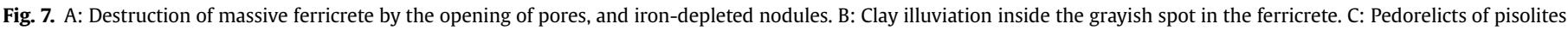
inside the mottled horizon. D: Weathered mineral (rutile) in the soft nodular horizon.

geomorphological events is consistent with the hypothesis of autochthonous sequence in our study area.

The favorable conditions for intense weathering of sandstone and hematitic concentration in soils forming crusts are high temperature, free drainage, and high water deficit in dry periods (Schwertmann and Taylor, 1989). After the deposition of Serra da Galga Member under aridic condition, the regional climate has fluctuated along the geological time, showing several alternances between dry and wet climate (Salgado-Labouriau et al., 1998). Also, the climates in South America have become progressively more humid since the Jurassic, and in the Eocene ( $50 \mathrm{Ma}$ ) an extensive ferruginous crust was formed in the central part of Brazil, under contrasted tropical climate with prolonged dry season (Tardy, 1993).

According to Fernandes and Ribeiro (2015), the lithostratigraphic subdivision of Marília Formation in lower Member Ponte Alta and upper Member Serra da Galga corresponds to a posterior differentiation of facies. The microfabric characteristics indicate that the occurrence of calcrete in the Member Ponte Alta results from the action of both pedogenic and groundwater processes (Fernandes, 2010; Fernandes and Ribeiro, 2015). The presence of calcrete has contributed to maintain the flat relief of the chapada.

Based on this proposition, the argillaceous sandstone of Serra da Galga Member remained suspended in the landscape under oxidative conditions over a long period. Chemical weathering by means of free fluids in the pediplained hinterland and on the sedimentary bodies helped to decompose labile constituents from the parent material, enhancing the thickness of the kaolinite formation with ferricrete and/or Ferralsol (Dill, 2016). The chemical and mineralogical results obtained for the profile indicate intense weathering of primary minerals which leads to a rapid and intense leaching of metallic cations, producing secondary products, e.g. kaolinite, gibbsite and accumulation of iron oxides.

Long exposure and stable tectonics tend to favor preservation of deep and highly evolved weathering residua. In the past, in the Brazilian, Australian, and tropical African Plateaus these conditions were satisfied (Pope, 2013). Based on Thomas (1994) the studied plateau presented the optimal climatic, topographic, tectonic and historical conditions to develop deep weathering mantle and ferricrete. Currently, the nodular ferruginous soil appears to be relics of ancient ferricrete which are now being destroyed under the more humid climatic conditions that prevail today (Tardy et al., 1991). Also, according to Maignien (1966), the sandstones are greatly susceptible to the ferrugination because they have a porous matrix facilitating the development of nodules, crusts and cores clayey which occupy the volume of the rock.

Finally, lateritic cover with pisolites is frequent on the flat plateaus $>800 \mathrm{~m}$ of altitude in Central Brazil (Mato Grosso, Goias and Minas Gerais States), covering different lithostratigraphic units. In the Paraná Basin, the lateritic material has close relationships with the bedrock (Sousa Junior et al., 1983). In this area, the profiles of weathering show a frequent impoverishment of sand and the pronounced enrichment of clay. The sandstone is penetrated by "tongues" of weathering, remaining some cores as resistate, which are later altered. This feature appears as a typical autochthonous development of soil, and it is visible only where there is a rupture of the relief (border of the plateau or in the incision of valleys). In our studied profile, fragments of sandstone (resistate core) occur in the three layer (mottled, ferricrete and pisolitic layers), only decreasing in topsoil.

\section{Conclusion}

The microscopic, chemical and mineralogical information obtained in the profile show that the strong weathering in lateritic environment has deeply altered the structure, the chemical and mineralogical composition of the argillaceous sandstone of Serra da Galga Member. The evolution of the saprolite toward the in situ iron 
crust was facilitated by the structure of the sedimentary rock.

The claystone and siltstone layers' present in the sandstone of Serra da Galga Member contributed with the microporosity required for hematite precipitation and accumulation. The lithic fabric is preserved by concentration of iron oxides, transforming the saprolite directly into ferricrete. The geological and paleoclimatic history were the constraints to form ferricrete while the more humid conditions drive in it geochemical and mechanical degradation recognized in a clayey and pisolitic profile.

\section{Acknowledgments}

This research was supported by the FAPESP (Process $\mathrm{N}^{\circ} 2014 /$ 01131-4). The authors are grateful to Dr. Antenor Zanardo for the identification of primary minerals.

\section{References}

Ambrosi, J.P., Nahon, D., 1986. Petrological and geochemical differentiation of lateritic iron crust profile. Chem. Geol. 57, 371-393.

Baccaro, C.A.D., 1991. Unidades geomorfológicas do Triângulo Mineiro: estudo preliminar. Soc. Nat 5-6, 37-42.

Beauvais, A., 1999. Geochemical balance of lateritization processes and climatic signatures in weathering profiles overlain by ferricretes in Central Africa. Geochim. Cosmochim. Ac 63 (23-24), 3939-3957.

Beauvais, A., 2009. Ferricrete biochemical degradation on the rainforest-savannas boundary of Central African Republic. Geoderma 150, 379-388.

Beauvais, A., Ritz, M., Parisot, J.-C., Bantsimba, C., Dukhan, M., 2004. Combined ERT and GPR methods for investigating two-stepped lateritic weathering systems. Geoderma 119, 121-132.

Boulangé, B., 1984. Les formations bauxitiques lateritiques de Côte d'Ivoire: les facies, leur transformation, leur distribution et l'evolution du modèle. Travaux Documents de l'ORSTOM 175, 341.

Butt, C.R.M., Lintern, M.J., Anand, R.R., 2000. Evolution of regoliths and landscapes in deeply weathered terrain - implications for geochemical exploration. Ore Geol. Rev. 16, 167-183.

Chardon, D., Chevillotte, V., Beauvais, A., Grandin, G., Boulangé, B., 2006. Planation, bauxites, and epeirogeny: one or two paleosurfaces on the West African margin? Geomorphology 82, 273-282.

CPRM- Serviço geológico do Brasil, 2003. Mapa geológico do estado de Minas Gerais. Escala 1, 1000000.

Delvigne, J.E., 1998. Atlas of Micromorphology of Mineral Alteration and Weathering. The Canadian Mineralogist, Special Publication 3. ORSTOM Edition, 494 pp.

Dias-Brito, D., Musacchio, E.A., Castro, J.C., Maranhão, M.S.A., Suarez, J.M., Rodrigues, R., 2001. Grupo Bauru: uma unidade continental do Cretáceo do Brasil - concepções baseadas em dados micropaleontológicos, isotópicos e estratigráficos. Rev. Paléobiologie 20, 245-304.

Didier, P., Nahon, D., Fritz, B., Tardy, Y., 1983. Activity of water as a geochemical controlling factorin ferricretes. A thermodynamic model in the system kaolinite Fe-oxihydroxide Fe-Al. Sci. Géol. Bull. 71, 25-34.

Dill, H.G., 2016. Kaolin: soil, rock and ore: from the mineral to the magmatic, sedimentary and metamorphic environments. Earth-Science Rev. 161, 16-129.

EMBRAPA, Centro Nacional De Pesquisa Agropecuária., 1997. Manual de métodos de análise de solo. Embrapa, Rio de Janeiro.

Eze, P.N., Udeigwe, T.K., Meadows, M.E., 2014. Plinthite and its associated evolutionary forms in soils and landscapes: a review. Pedosphere 24 (2), 153-166.

Fernandes, L.A., 1998. Estratigrafia e evolução geológica da parte oriental da Bacia Bauru (Ks, Brasil). Ph.D. Thesis. Universidade de São Paulo, Brazil, p. 216.

Fernandes, L.A., 2010. Calcretes e registros de paleossolos em depositos continentais neocretaceos (Bacia Bauru, Formaç ao Marília). Rev. Bras. Geociências 40 (1), $19-35$.

Fernandes, L.A., Ribeiro, C.M.M., 2015. Evolution and palaeoenvironment of the bauru basin (upper cretaceous, Brazil). J.S. Am. Earth Sci. 61, 71-90.

Harnois, L., 1988. The CIW index: a new chemical index of weathering. Sediment. Geol. 55, 319-322.

Hong, H., Gu, Y., Yin, K., Zhang, K., Li, Z., 2010. Red soils with white net-like veins and their climate significance in south China. Geoderma 160 (2), 197-207.

IUSS Working Group WRB, 2006. World Reference Base for Soil Resources 2006. World Soil Resources Reports 103. FAO, Rome, 128 pp.

King, L.C., 1956. A geomorfologia do Brasil oriental. R. Bras. Geogr. XVIII, 3-119.

Lanson, B., Beaufort, D., Berger, G., Bauer, A., Cassagnabe, A., Meunier, A., 2002. Authigenic kaolin and illitic minerals during burial diagenesis of sandstones: a review. Clay Min. 37, 1-22.

Lindbo, D.L., Stolt, M.H., Vepraskas, M.J., 2010. Redoximiorphic features. In: Stoops, G., Marcelino, V., Mees, F. (Eds.), Interpretation of Micromorphological Features of Soil and Regoliths. Elsevier, Oxford, pp. 129-148.
Löhr, S., Grigorescu, M., Cox, M., 2010. Genesis of ferruginous concretions in a ferric soil and implications for past and present iron mobility. In: 19th World Congress of Soil Science, Soil Solutions for a Changing World. Brisbane, Australia. PP. 31-34.

Maignien, R., 1966. Compte rendue de recherches sur les latérites. UNESCO, Paris, 155pp.

Mamede, L., Ross, J.L.S., Santos, L.M., Nascimento, M.A.L.S., 1983. Geomorfologia. In: Projeto RadamBrasil - Levantamento de Recursos Naturais. Folha, SE. 22 Goiânia, pp. 349-412.

Marques, J.J., Schulze, D.G., Curi, N., Mertzman, S.A., 2004. Major element geochemistry and geomorphic relationships in Brazilian Cerrado soils. Geoderma 119, 179-195.

McKay, L.D., Driese, S.G., Smith, K.H., Vepraskas, M.J., 2005. Hydrogeology and pedology of saprolite formed from sedimentary rock, eastern Tennessee, USA. Geoderma 126, 27-45.

Menegazzo, M.C., Catuneanu, O., Chang, H.K., 2006. The South American retroarc foreland system: the development of the Bauru Basin in the back-bulge province. Mar. Petrol. Geol. 73, 131-156.

Monteiro, H.S., Vasconcelos, P.M., Farley, K.A., Spier, C.A., Mello, C.L., 2014. (U-Th)/ He geochronology of goethite and the origin and evolution of cangas. Geochim. Cosmochim. Ac. 131, 267-289.

Motta, P.E.F., Carvalho Filho, A., Ker, J.C., Pereira, N.R., Carvalho Junior, V., Blancaneaux, P., 2002. Relação solo-superfície geomórfica e evolução da paisagem em uma área do Planalto Central Brasileiro. Pesqui. Agropecuária Bras. 37 (6), 869-878.

Muller, J.P., Bocquier, G., 1986. Dissolution of kaolinites and accumulation of iron oxides in lateritic-ferruginous nodules: mineralogical and microstructural transformations. Geoderma 37, 113-136.

Nahon, D.B., 1991. Introduction to the Petrology of Soils and Chemical Weathering John Wiley \& Sons, New York, 313 pp.

Nahon, D., 2003. Altérations dans la zone tropicale. Signification à travers lês mácanismes anciens et/ou encore actuels. C.R. Geosci. 335, 1109-1119.

Nahon, D., Janot, C., Farpoff, A.M., Paquet, H., Tardy, Y., 1977. Mineralogy, petrography and structures of iron crusts (ferricretes) developed on sandstones in the Western part of Senegal. Geoderma 19, 263-277.

Nahon, D., Melfi, A.J., Conte, C.N., 1989. Présence d'un vieux système de cuirasses ferrugineuses latéritiques em Amazonie Du Sud. As transformation in situ em latosols sous La forêt équatoriale actuelle. C. R. Acad. Sci. Paris 3008, 755-760.

Pope, G.A., 2013. Weathering in the tropics, and related extratropical processes. In: Shroder, J., Pope, G.A. (Eds.), Weathering in the Tropics, and Related Extratropical Processes. Academic Press, San Diego, pp. 179-196.

Ribeiro, D.T.P., 2001. Diagênese das rochas do Membro Serra Da Galga, Formação Marília, Grupo Bauru (Cretáceo Da Bacia Do Paraná), na região de Uberaba, Minas Gerais. Ver. Bras. Geoc 31 (1), 7-12.

Salgado-Labouriau, M.L., Barberi, M., Ferraz-Vicentini, K.R., Parizzi, M.G., 1998. A dry climatic event during the late Quaternary of tropical Brazil. Rev. Palaeobot. Palinol. 99, 115-129.

Schwertmann, U., Taylor, R.M., 1989. Iron oxides. In: Dixon, J.B., Weed, S.B. (Eds.) Minerals in Soil Environments. Soil Sci. Soc. Am., Madison, pp. 379-438.

Silva, F.A.M., Assad, E.D., Evangelista, B.A., 2008. Caracterização climática do bioma cerrado. In: Sano, S.M., Almeida, S.P., Ribeiro, J.F. (Eds.), Cerrado: ecologia e flora, vol. 1. Embrapa, Rio de Janeiro, pp. 69-88.

Singh, B., Gilkes, R.J., 1996. Nature and properties of iron rich glaebules and mottles from some south-west Australian soils. Geoderma 71, 95-120.

Sousa Junior, J.J., Freire, F.A., Oliveira, F.C., Silva, R.H., Bonow, C.W., Moreira, H.L. 1983. Geologia: geologia da Bacia Sedimentar do Paraná. In: Projeto RadamBrasil - Levantamento de Recursos Naturais, vol. 31. Folha, SE. 22 Goiânia pp. 23-348.

Stoops, G., Marcelino, V., Mees, F., 2010. Interpretation of Micromorphological Features of Soil and Regoliths. Elsevier, Oxford, 720pp.

Suguio, K., 1973. Formação Bauru. Calcários e sedimentos detríticos associados. Free-docency thesis. Universidade de São Paulo, São Paulo, 236 pp.

Tardy, Y., 1993. Pétrologie des latérites et des sols tropicaux. Masson, Paris, 459 pp.

Tardy, Y., Roquin, C., 1992. Geochemistry and evolution of lateritic landscapes. In: Martini, I.P., Chesworth, W. (Eds.), Weathering, Soils \& Paleosols, Developments in Earth Surface Processes, vol. 2. Elsevier, pp. 407-471.

Tardy, Y., Kobilsek, B., Paquet, H., 1991. Mineralogical composition and geographical distribution of African and Brazilian peri Atlantic laterites. The influence of continental and tropical paleoclimates during the past 150 million years and implications for India and Australia. J. Afr. Earth S. C. 12 (1/2), 283-295.

Thomas, M.F., 1994. Geomorphology of the Tropics. Wiley, Chichester, 460 pp.

Tucker, M.E., 2014. Rochas sedimentares: guia geológico de campo, $4^{\circ}$ edição. Bookman, Porto Alegre. 324 pp.

Twidale, C.R., Bourne, J.A., 1998. The use of duricrusts and topographic relationships in geomorphological correlation: conclusions based in Australian experience. Catena 33, 105-122.

Vasconcelos, P.M., Renne, P.R., Brimhall, G.H., Becker, T.A., 1994. Direct dating of weathering phenomena by $49 \mathrm{Ar} / 39 \mathrm{Ar}$ and $\mathrm{K}-\mathrm{Ar}$ analysis of supergene $\mathrm{K}-\mathrm{Mn}$ oxides. Geochim. Cosmochim. Ac. 58 (6), 1635-1665.

Zanardo, A., Oliveira, M.A.F., Del Lama, E.A., Carvalho, S.G., 1996. Geologia do Grupo Araxá de Passos-São Sebastião do Paraíso, sul de Minas Gerais. Geociências 15 (1), 253-278. 